Levels of governance and multi-stage policy process of brownfield regeneration: a comparison of France and Switzerland

Dr. Lauren Andres

Lecturer in Spatial Planning

Centre for Urban and Regional Studies

University of Birmingham, Edgbaston, Birmingham, B15 2TT, UK

Office : $+44(0) 1214145021$

Fax : +44 (0) 1214143279

L.Andres@Bham.ac.uk 


\title{
Levels of governance and multi-stage policy process of brownfield regeneration: a comparison of France and Switzerland
}

\begin{abstract}
This paper compares the multi-stage policy process of brownfield regeneration in France and in Switzerland, two decentralised though different countries that haven't fully addressed the issue of brownfield regeneration at a national level. This paper aims to understand why they have not shared and are still not sharing similar path towards the inclusion of brownfield sites in national planning frameworks. Drawing on the examples of national policies conducted in England, in Germany and in the US, the paper argues that whereas Switzerland is moving quickly to a national programme of brownfield regeneration highly anchored in an ambition of preserving natural spaces against urbanization, France, on the other hand, is sustaining a persistent national concern for social housing estates giving flexibility and leeway to local and regional authorities as regards to land use management and brownfield regeneration.
\end{abstract}

Keywords: regeneration, brownfield, policy, planning, France, Switzerland

\section{Introduction}

De-industrialisation, economic crisis and social changes in North American and European countries since the mid 60s have led to a profusion of brownfield lands resulting in economic, environmental and planning concerns on the agenda of national and local policies (Couch \& al. 2003). These concerns have sat within broader perspectives of urban regeneration, economic development or soil remediation. An abundant literature is available on this topic, particularly in Europe and in North America (Dixon, 2006; Raco and Henderson, 2006; Dair and Williams, 2006; Ganser and Williams, 2007; Dull and Wernstedt, 2010; Schulze Baing, 2010; Adam \& al., 2010), within which two categories of countries can be identified: those who have a national policy for strategic brownfield reuse sitting within some principles of urban containment and environmental/economic policies and those who are essentially implementing local and regional policy of brownfield regeneration part, or not, of broader strategies of urban development.

Schulze Baing (2010, p. 25), quoting Syms \& al. (2003), argued that the UK, France and Germany share a common national policy concern, "with targets and specific instruments to promote the reuse of land in place and in the process of being developed". This concern is significant as well for the US and Canada (Adams \& al.2010). However such a statement is irrelevant in the French case (Andres, 2008; Andres \& Bochet, 2010). France better belongs to the second category of countries where the concern for brownfield regeneration has essentially been addressed in local and regional policies despite localised land-use strategies. This statement is also valid in Switzerland (Andres, 2008; Andres \& Bochet, 2010) even if the country is currently at a turning point: for the five last years growing national interest in brownfield regeneration has been noticeable with the possibility of the development of a national policy in the future. Of course it could be argued that whereas economic downturns have been significant in England, Germany and in the US, in France and Switzerland they were less disastrous. More interest started to be shown in brownfield regeneration when planning for sustainable cities became a key challenge from the mid-1990s and when urban containment policies began to be questioned. However this answer is not sufficient to explain such a distinct policy trajectory. 
While questioning why these two countries haven't fully addressed the issue of brownfield regeneration at a national level this paper aims to understand why they have not shared and are still not sharing similar path towards the inclusion of brownfield sites in national planning frameworks despite two strongly (though differently) decentralised political system. In France despite some territorial attempts targeting brownfield sites, regeneration has essentially remained a decentralised matter highly encompassed in urban development issues. In Switzerland on the other hand it has become a matter of rising national interest since brownfield sites have been considered as key priority for a more efficient use of space. Drawing on the conceptual model of multi-step policy development designed by Adams \& al. (2010) the paper aims to demonstrate that the lack of a national agenda based on coherent discourses (1), strategies (2) and actions (3) has been significant of segmented policy priorities dispatched over time between local and national levels of governance and within more or less accurate definitions of brownfield sites.

Assessing the French and Swiss case offers a relevant scope of analysis for this, particularly as a gap remains in understanding and comparing the purposes of brownfield land regeneration in both of these two countries over the last 20 years. Key attention in academic research has essentially been given to the US, the UK and Germany (Dixon, 2006; Raco \& Henderson, 2006; Dair \&d Williams, 2006; Ganser and Williams, 2007; Dull and Wernstedt, 2010; Schulze Baing, 2010; Adam \& al., 2010). Only limited research has been published on this particular topic in France (Datar, 1991; Chaline, 1999; Andres, 2008; Andres, Bochet, 2010; Lamard and Vitoux, 2006) and in Switzerland (Andres, 2008; Andres, Bochet, 2010; Rey, 2006, 2007; Aspan, 1997; Rerat \& al., 2010); most of which have encompassed brownfield sites within broader concerns of gentrification (Rerat \& al., 2010), heritage (Lamard and Vitoux, 2006) or sustainable development and eco-neighbourhoods (see Rey, 2006, 2007).

After providing an overview of existing national policies and priorities of brownfield regeneration, particularly in England, the USA and Germany, the paper presents the methodology of research and the analytical framework based on a conceptual model of policy development. The next two sections then analyse the French and Swiss cases. Comparative lessons are finally drawn in the conclusion section particularly with regard to the challenges faced by brownfield reuse in these two differently decentralised planning systems.

\section{Brownfield regeneration and urban containment policies: a central matter for national governments?}

Brownfield sites can be broadly defined as any land or premises, vacant, derelict or contaminated, previously used or developed but which is not currently in full use and is not readily available for immediate use without some form of intervention (Alker \& al,. 2000). However, in practice this definition varies nationally and locally. For example, in England, Planning Policy Statement 3 (DCLG, 2006b) defines brownfield sites as "previously developed land that is unused or may be available for development. It includes both vacant and derelict land and land currently in use with known potential for re-development. It excludes land that was previously developed where the remains have blended into the landscape over time" (ODPM, 2005, p. 77). The United States Environmental Protection Agency within the Brownfields Action Agenda characterizes them as "abandoned, idled, or underused industrial and commercial facilities where expansion or redevelopment is complicated by real or 
perceived environmental contamination" (US EPA, 1995, p. 1). In Germany as noted by Weitkamp (2006) there is no formal definition of brownfield sites however there is a broader understanding that brownfield are used lands (contaminated or not) for which new use has not been found. These wide or more restricted definitions impact how the redevelopment of these areas is addressed as accordingly their reuse is associated to broader policy priorities such as economic development, environmental concerns or urban containment policies.

National policies for strategic brownfield reuse can be identified in a set of countries paying a particular attention to the promotion of the sustainable reuse of land and the promotion of urban containment policies (Dixon, 2006; Schulze Baing, 2010) part - or not - of specific actions targeting contaminated sites. Sustainable development and urban regeneration are intimately related as both sit within the broader debate on compact cities (Camagni and Gibelli, 1997; Breheny, 1997; Burton, 2000; Frey, 1999, Williams \& al., 2000) and the aim of achieving a sustainable urban form through the recycling of land (see for example, Adams and Watkins, 2002; Breheny and Rookwood, 1993; Jenks \& al, 1996; Power and Mumford, 1999; Rudlin and Falk, 1999; Williams \& al, 2000; Dair and Williams, 2006). Broadly speaking, strategic brownfield regeneration relates to the aim of reducing the pressure on undeveloped lands and need for urban sprawl (see for example Uhel, 2006; Couch, Leontidou and Petschel-Held (Eds), 2007; Fina and Siedentop, 2008). Urban containment policies are defined by Jenks, Burton and Williams (1996) as ways to encourage urban regeneration, town centre revitalization, higher densities and mixed use development amongst other objectives. Despite avid critics against the limits of the compact city (for example, Breheny, 1992; Breheny and Rookwood, 1993; Haughton and Hunter, 1994), such ambitions have been largely transposed in key local, regional and national spatial planning strategies in Europe and North America.

Containing urban development and particularly avoiding or limiting its development on greenfield land has been a central objective of national planning policies since the $40 \mathrm{~s}$ in Europe and most notably in the UK (Hall, 1974; Millward, 2006; Schulze Baing, 2010). Dair and Williams (2006) have argued that this has led to further debates especially with regard to urban renaissance (Barton \& al, 2003; CABE, 2002; Carmona \& al, 2001; DETR, 2000a and 2000b; Duxbury, 2003; Parkinson \& al, 2004; Urban Task Force, 1999) where reuse of brownfield spaces is put at the core of specific programmes which aim to simultaneously promote urban containment and development to meet housing need (a, 1998; DETR, 2000; Barker, 2003; 2004). As soon as in 2000 the Planning Policy Statement 3 Housing (ODPM, 2000) included policy and guidance in relation to land for housing, particularly a national target for brownfield redevelopment with $60 \%$ of all new development destined for re-used land in urban areas (DETR, 2000a). As noted by Dixon (2006), the Planning Directorate of the Office of the Deputy Prime Minister in 2001 associated brownfield regeneration to economic and social regeneration of surrounding areas; environmental improvements of the sites themselves; and reduction in development pressures on greenfield sites. Reusing brownfield land and providing new housing was further emphasised in the Barker Review in 2003; it was complementary to the 'sequential' approach introduced as soon as in 1996 in order to prioritize town-centre retail sites before out-of-town sites for all city-centre redevelopment projects (Dixon, 2006).

The British pro-active national approach to brownfield regeneration can be contrasted with other national approaches to brownfield regeneration. As argued by Schulze Baing (2010, p. 34), whereas England and Germany are sharing same national concerns and targets, in Germany, the "attitude towards processes of urban sprawl and other forms of post modern urbanized landscapes is not as negative and much more diverse as one might be familiar in England, reflected in discussions about 
the Zwischenstadt phenomenon"; in other words the idea of "shifting the focus of urban and regional planning away from the compact centres towards the periphery and the spaces in between cities" is central (Schulze Baing; 2010, p. 29). This approach towards urban containment as a key priority for brownfield regeneration can be contrasted with the US case where economic development has mainly been the driver of a national policy and strategy for brownfield regeneration.

As noted by Adams \& al. (2010, p.91), quoting Bartsch (1996), "US attention has focused on economic development projects that seek to create or preserve businesses, jobs and taxation structures in the inner city, particularly in Northeast and Midwest areas affected by deindustrialisation". Actions and policies taken towards brownfield were also related to the consequences of federal and state laws imposing liability on parties for environmental cleanup (Dull and Wernstedt 2010). The EPA Brownfields Program has been part of a broader integration of economic and environmental priorities in federal government hazardous waste policy (Greenberg \& Issa, 2005; Hula, 2001). It was introduced in 1995 by the Environmental Protection Agency to help clarify the federal government's role in brownfield land as state authorities were conducting cleaning programmes in addition to making funds available for the most contaminated sites (Adams \& al., 2010). Further actions were taken in 1997 in the Brownfields National Partnership Action Agenda. The EPA Brownfields Program was expanded and given statutory footing by the Small Business Liability Relief and Brownfields Revitalization Act of 2002 (Dull and Wernstedt 2010). Priorities of these programmes were given to economic and environmental benefits, community involvement, environmental justice considerations and the effect of the brownfields redevelopment on the surrounding community (Solitare \& Greenberg, 2002).

Consequently whereas the US, Germany and England have shared a common national concern towards brownfield redevelopment, it appears that different drivers were at the core of these policies: on one hand, the protection of greenfield and urban containment policies, in England and to a certain extent in Germany, and, on the other hand, economic development and environmental considerations in the US. Whereas in England, the national policies were encouraged by a centralised planning system, they were complementary to the actions of federal governments in the US and in Germany (Adams \& al., 2010; Dull and Wernstedt 2010; Ganser and Williams, 2007; Schulze Baing, 2010). This succinct overview contrasts with the absence of proper national policies (on top of an official definition of brownfield) in other European countries for example as noted by Ganser and Williams (2007) in Austria, Spain or Holland accordingly to the results of the CABERNET project. The aims of the next sections are then to understand how this issue of brownfield regeneration has been addressed in France and Switzerland, what have been the past and current freezes in the policy process against a national brownfield agenda. Prior to this the methodology of analysis is to be developed.

\section{Analytical framework and methodology}

France and Switzerland are two countries characterized by a decentralised planning system. However the nature of the decentralisation process and the extent to which urban and planning issues have been a priority at national, regional and local level are different. 
In France, from 1950 planning became progressively one of the key national policies leading to the creation of a special agency in charge of territorial planning (the DATAR) in 1963. Urban development was therefore a matter of national interest. Since then key sectors have been privileged at all governance levels particularly transport, industrial development, affordable housing and later on sustainable development. Despite the arrival of a socialist president in 1981 and of several socialist governments in the next 10 years the conception of national policies was not deeply re-formalized; all of them were driven by a market-led frame of reference (Muller, 1990) implying the ideas of competition, evaluation and cost control. From the beginning of de-industrialisation (in the 1970s) local authorities started to share power with the State as regard to economic development (Nicholls, 2005). This tendency was consolidated with a series of decentralisation Acts in 1982 and then in 2002 giving local authorities more competencies over planning and economic development (Nicholls, 2005; Dumont, 1993). From 1983 to 1986, a series of powers were devolved from the national level; in particular the regional level became responsible for economic planning and the local level (the communes) for urban planning. From 1992 (through the Acts ATR ${ }^{1}$, Pasqua and Chevènement) additional urban divisions ("communautés de commune", "communauté de ville", "communauté d'agglomération") which gather together a range of communes gave more powers to local urban levels such as economic development, territorial planning, housing or urban policies (Ancien, 2005; Cole, 2006; Girardon, 2006; Monod and De Castelbajac, 2006).

Switzerland on the other hand is a multi-party, federal, parliamentary republic and a direct democracy. As noted by Rerat \& al. (2010) Switzerland is characterized by a hierarchical planning system in which the regional government (Cantons) are the most powerful decision makers (Aspan, 2004). The federal government only gives guidelines, provides general policy for spatial development and initiates debates. The role of the Federal government for planning is to edict principles / frames of action, provide Acts in specific sectors (transport or industrial development for e.g.) and let the Cantons in charge of elaborating and implementing territorialised directory plans (Aspan, 2004). Cantons themselves delegate specific competencies to communes. Switzerland presents an unusual particularity because planning has been disconnected to cities until the mid 1990s. The first Act on Territorial Planning (LAT) in 1979 did not include any articles that might be affecting private land ownership and never mentioned the word "city". Whereas Switzerland has always been characterised by a high urbanisation pressure due to the shortage of land available for development, it has paid significant attention to the preservation of its landscape and its environment (Aspan, 2004; Salomon Cavin, 2005). As noted by Walter (1996) the importance given by the federal government to rural attributes, core to the Swiss identity led to a "city psychosis". This perception evolved in the late 1990s when cities finally became a national priority (Gerosa, \& al., 1988; Kübler \& al. 2005; Salomon Cavin, 2005) simultaneously to the importance given to sustainable development. In 1999 the article.50, alinea. 3 of the Federal Constitution, asserted the importance of cities and urban areas for socio-economic development. Nevertheless it did not entirely led to a successful integration and cooperation between the different levels of government, including urban areas and cross-border regions (Kübler, \& al. 2005).

Demonstrating that France and Switzerland don't share a national agenda for brownfield regeneration in contrast to America or England and explaining why such a gap relies on a lack of

\footnotetext{
${ }^{1}$ Loi ATR relative à l'administration territoriale de la République (6 Février 1992), Loi Pasqua (4 Février 1995), Loi Chevènement (12 Juillet 1999
} 
coherence in the policy maturity process stresses the importance of temporal stages. These stages include an evolution of the policy priorities towards brownfield sites as well as of the governance process (particularly in a decentralised system). It questions how responsibilities towards those priorities encompassing brownfield regeneration have been (re)distributed. These stages are indeed related to varied pace and direction of policy change. Temporary stages refer also to the policy formulation process discussed by Adams \& al. (2010). The authors argued that this dialectic process is significant of how "policy problem is reconceptualised over time as a development opportunity" (p76). It first involves a political interest (1) aiming to define and map the significance of the problem; it "requires recognition that the social and economic forces that made former uses redundant deserve as much attention as the physical characteristics of the redundant sites themselves" (Adams \& al., 2010, p.78). Then, a political will (2) appreciates the contribution of the object and includes the production of reports and inventories aiming to grasp a thorough understanding of the nature of the problem; it does also involve a political commitment including the adjunction of resources and the implementation of concrete actions. It leads finally to the enlargement of the stakeholders involved particularly through the participation of the private sector (3) (Adams \& al., 2010). Although other authors have highlighted the limits of such staged models due to their static and rational character (quoting the work of Downs, 1972; Cohen \& al., 1972; Kingdon, 1984; Anderson, 1997; Hudson and Lowe, 2004) they acknowledge their usefulness in assessing brownfield policy development. This paper adopts the same framework (making though a formal distinction between political will and commitment as it focuses on the discontinuities rather than on the linear process, which involves a range of positions and actions worth separating in two distinct stages); it draws on the main hypothesis that the absence of a coherence national agenda towards brownfield sites is related to a lack of coherence within and between the stages of political interest (discourse), political will (strategy) and political commitment (action). It also stresses the fact that these three stages depend on the definition of brownfield lands and relays on a common understanding of what is a brownfield site. In the context of two decentralised countries it also argues that the levels of governance are influencing the policy process particularly the policy priorities. With regard to brownfield redevelopment (see section 2) these priorities can be divided in four main groups: economic development, contamination, housing and urban containment.

The figure below summarizes the analytical framework which is going to be used to assess how the issue of brownfield redevelopment has been addresses (or not) in discourses, strategies and actions in France and Switzerland. The results presented in this paper are based on empirical research from a project conducted in France and Switzerland from 2004 and 2008 (Andres, 2008) and regularly updated in the following three years. This research included the collection and the analysis of both secondary and primary data in the form of documentary reviews (range of reports published by national agencies and local authorities, academic papers, laws and acts, planning guidance and frameworks) and interviews with national and local decision makers and practitioners, both in the public in private sectors in Paris, Grenoble, Marseille, Lausanne, Geneva and Bern. This includes local planning departments, planning consultancy and development companies, national renewal/regeneration agencies, regional and national environmental and real estate agencies. Interviews in Paris and Bern, where national agencies are located, provided generic information on how the issue of brownfield regeneration has been addressed at national level. Grenoble, Marseille, Geneva and Lausanne offered a more localised scope of analysis with regard to secondary and third cities. All interviews covered the following streams: $1 /$ the evolution of the perception of brownfield sites and how they have been included (or not) in reports and inventories; $2 /$ the evolution of policy 
priorities within which brownfield sites were part of (or not); $3 /$ an understanding of the paradigm of urban renewal and regeneration; 4/ an understanding of the different partnerships, of the funding available and the levels of governance involved.

Figure 1: Theoretical framework of brownfield policy development

Time towards policy maturity:

- Evolution of priorities

- Evolution of governance (decentralisation)

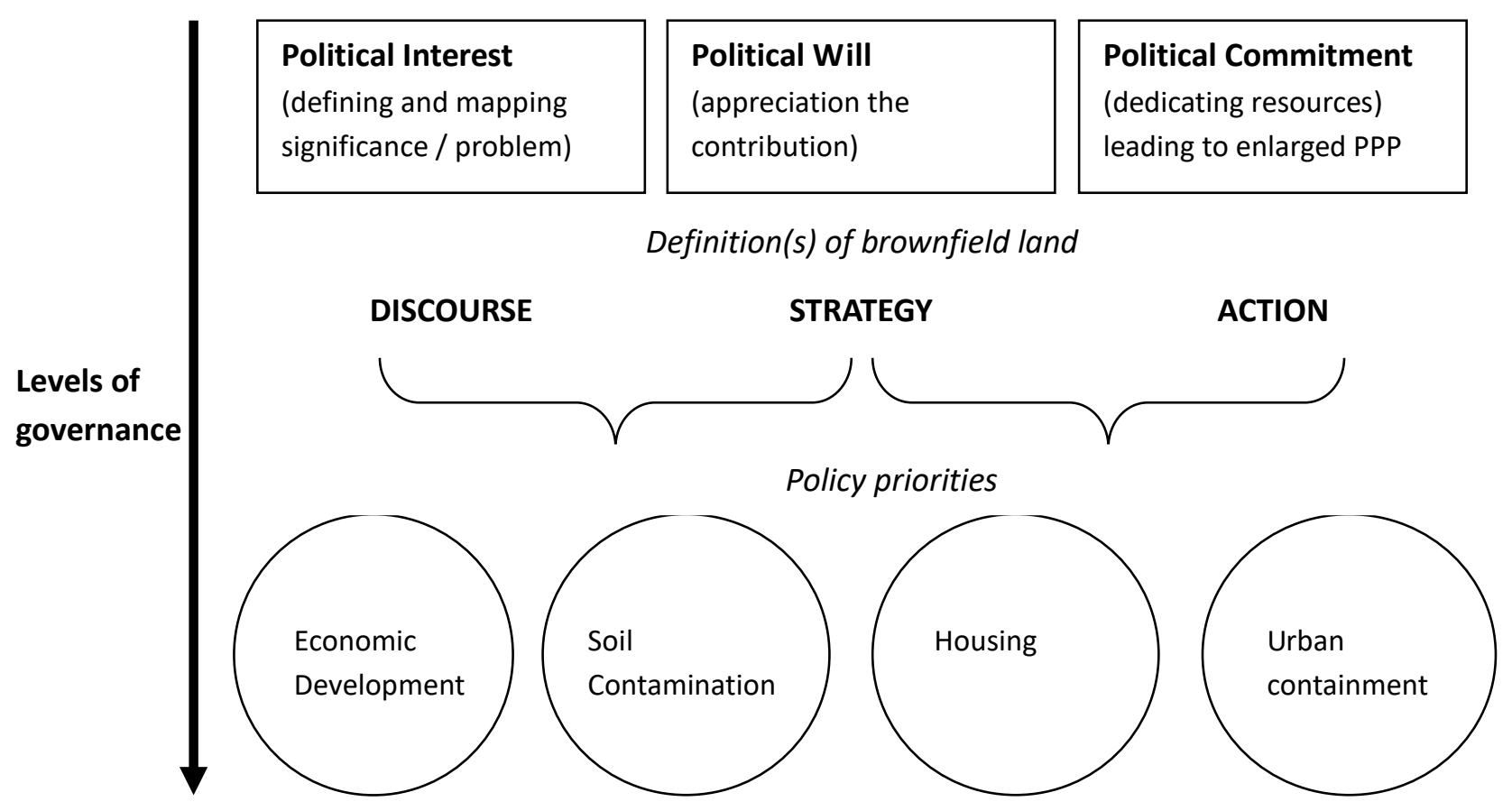

Source: Andres, 2011 


\section{3: The French case: localized and sectoral national political interest and will versus local political commitments}

There is no distinction in the French terminology between fallow land, industrial brownfield or urban wasteland: the word "friche" is used for all. The only distinction is made through the use of an adjective (agricultural, industrial or urban for example) to describe its context. As noted by Raffestin (1997) the concept of brownfield has been built on the concept of fallow land; from a meaning essentially focused on a land not cultivated it evolved towards a broader meaning to characterize a space left without care (Raffestin, 1997). In the second half of the $20^{\text {th }}$ century the word "friche" is used to describe lands not used for agricultural purposes due to speculative strategy; its meaning then evolved towards urban spaces. The reference to derelict and under-uses spaces that have lost their original function has been transposed to buildings and areas (Andres, 2008). Contextually a "friche" has therefore primarily been industrial (in a context of desindustrialisation) and then more broadly urban. Whereas the industrial brownfield was initially compared to a "cancer" (Datar, Lacaze 1986), an "obsolete and depredated area" (Datar, 1987), or an "escheated area" (STU, 1988) it has since evolved towards a more positive perception as an "opportunity" (Chaline, 1999). This acknowledgement is shared by a wide range of actors, from local authorities to private stakeholders. There is a general consensus amongst the interviewees ${ }^{2}$ that "there is a lack of land available for development. Consequently most of the brownfield sites are of interest" ${ }^{3}$. Nonetheless despite this common understanding there is in France no national policy towards brownfields sites. Using the policy development model developed in the previous section this gap can be explained by the conjunction of a set of factors which led to a disjunction between the different steps of the policy process never fully fulfilled and related to each other.

First of all it is worth noticing that there is no official or at least commonly accepted definition of brownfield sites (i.e. friche) despite what argued by Cabernet (2006). The concept remains very fuzzy and various definitions are given depending on the former activity of the site (industrial brownfield, rail brownfield, port brownfield, administrative brownfield), on its size, and the fact that it requires or not remediation (Communautés Urbaines de France, 2010). "There would be a need to decide what really a "friche" is. However there is such a common use of the word that it is now probably too late" . The fact that no institutions stepped forward in providing a generic definition then used in key planning and policy documents has been a key obstacle to gain a thorough understanding of the problem. This indeed has been reinforced years and years particularly with the enlargement of the use of the word "friche" in the common language.

Secondly the limited national political interest towards brownfield can also be explained by two key factors: $1 /$ up to the mid 80 s only limited areas are strongly affected by desindustrialisation; despite some attempts in mapping the significance of the problem and producing reports (Datar,Lacaze, 1986; Datar, 1987; Datar, 1991), limited resources are allocated for a short period of time; $2 /$ from the 90s, while the position towards derelict sites tends to shift towards a more positive perception, brownfield land when incorporated within the paradigm of urban renewal are competing with a more problematic issue for public policy: the regeneration of deprived social housing estates. As stressed by a representative of a national development agency "Brownfields are not acknowledged as a real

\footnotetext{
${ }^{2}$ Both public and private interviewees working in the area of planning and development and defending this argument with regard to secondary, third cities

${ }^{3}$ Interview with Head of planning (national real estate agency), June 2006

${ }^{4}$ Interview with director of consultancy, regeneration agency, September 2006
} 
problem and do not involve specific fund allocation on the contrary to our "banlieues" and "grands ensembles" ${ }^{5}$.

Industrial brownfields started to be a matter of national and local concern at the beginning of the 80s when policy priorities such as economic development were already shared at different levels; several reports were published (STU, 1983; 1986; 1988, Datar, Lacaze, 1986; Datar, 1987; 1991) to assess the number of brownfield sites and point out the major challenges addressed to local economies and communities. However, no specific national policies or strategies were implemented, specifically because France was not characterized by "a problem of industrial decline (though these problems existed in some cities in the North and East of the country)" (Farthing and Carrière, 2007, p. 20). Only sectoral programmes (sometimes complementary to EU funding) were put in place in the most affected industrial regions to compensate the loss of jobs and to create new opportunities for industries to settle (Wachter, 1991; Le Gales and Tirmarche, 2004). Despite a national political interest, the will and commitment was extremely limited and localised. Simultaneously local councils and regional bodies became involved in supporting industries under threat and attracting new industries (Le Gales, 1993). The only way industrial brownfield redevelopment was addressed was through a sole economic/industrial scope (Vanier, 1997; Chaline, 1999; Andres, 2008). Local authorities were the main actors of these transformations especially for cities facing challenges of "life or death in a situation of severe economic decline" ${ }^{6}$. From such a defensive perspective (industrial brownfields are cancers and a battle is engaged, see Datar / Lacaze, 1986), they moved in the 90s (in a context of a decentralized planning system) toward a more market-led approach in which developers tended to play a very important role, keen to invest in central derelict areas (with moderate constraints of remediation and a good accessibility) and develop mixed used projects. Interest towards industrial brownfield sites were broadened to urban brownfield sites. This fostered the political will and commitment of local authorities to identify, facilitate and support the regeneration of such unused sites. In other words brownfield regeneration was clearly addressed at a local level, through local policies. At a national level it shifted from a limited in time economic interest (due also to a context of deindustrialization) to a real estate focus particularly through the paradigm on urban renewal.

The inclusion of urban brownfield sites in the paradigm of urban renewal demonstrated a political appreciation of their contribution for urban renaissance and sustainable planning; however a disjunction between political interest and commitment did not fulfill the process of policy maturity. Brownfield reuse therefore remained a local matter. This is partly related to the long tradition of national policy towards housing improvement throughout the $20^{\text {th }}$ century (Driant, 2009). From the 70s, urban policies ("politiques de la ville") have targeted deprived suburban social housing estates (see for example Bonneville, DATE; Le Gales and Mawson, 1995; Hall and Hickman, 2002; Le Garrec, 2006; Novarina, Pucci, 2004; Blanc, 2010). Several Acts were passed ${ }^{7}$, dedicated agencies for housing were created $^{8}$ and specific programmes ${ }^{9}$ put in place to enable this. These policies are currently

\footnotetext{
${ }^{5}$ Interview, December 2007

${ }^{6}$ Interview with a private consultant specialized in planning in regeneration, December 2007

${ }^{7}$ Loi $n^{\circ}$ 96-987 Pacte de relance pour la ville" in 1996, "Loi n²000-1208 relative à la solidarité \& au renouvellement urbains" in 2000 and "Loi Borloo $n^{\circ}$ 2003-710 d'orientation \& de programmation pour la ville \& la rénovation urbaine" in 2003

${ }^{8}$ For e.g. “Comité Habitat \& Vie Social” in 1977, “Comité Interministériel à la Ville “ in 2003, Agence National pour la Rénovation Urbaine in 2004
} 
acknowledged as in the core of national urban renewal policies. However the initial concept of "renewed cities" ("ville renouvelée") was actually developed in the early 1990s and broadly dealt with the disequilibrium of central industrial areas suffering from economic decline and social segregation (Freville, 2001); this concept initially developed in the Nord-Pas-de-Calais Region was rapidly transferred to broader national ambitions. The principle of "rebuilding the city on the city" ("reconstruire la ville sur la ville") was used as a key national frame of reference. Up to 1999 the ambition of "reconstruire la ville sur la ville" was included in the concept of "urban renewal" initially comprising brownfield regeneration and social housing estate renewal (Le Garrec, 2006).

Now, "urban renewal" evolved from a large conception of derelict spaces to a more restrictive definition promoted by two Acts in 2000 and 2004 ("Loi SRU" and "Loi Borloo") explicitly dedicated to social housing estates and less connected to the ambitions of "reconstruire la ville sur la ville". The concerns towards brownfield regeneration were therefore transferred in the agenda of sustainable planning. Sustainable development was positioned as a core national objective from 1995 and inserted in the French constitution in 2004 and the latest Acts "Loi Grenelle 1" (2009) and "Loi Grenelle II" (2010). It has become a way to legitimize a set of national objectives: mobility, social cohesion and land use. Further to the "Grenelle de l'Environnement" in 2007, considerations on a better use of land for development and the aim of "fighting against urban sprawl" have been transposed in proposals dedicated to climate change and energy. However brownfield sites are not identified as areas of action and no indicators or quotas (as in the UK) were put in place to favour their redevelopment. This can partly be explained by a lack of political commitment in the exception of localized real estate programmes launched as soon as from the early 70s: the "établissements publics foncier d'Etat" (Nord-pas de Calais created in 1990, West Rhone-Alpes in 1998, Lorraine in 1973) settled for some of them in several declining industrial regions. In these areas the government supported the creation of these specific organizations aiming to constitute a portfolio of land available for development.

More recently a programme conducted by the national environmental and energy management agency (Ademe, 2010) has aimed to fund the remediation costs of key projects of sustainable brownfield regeneration (Ademe, 2010) part of a broader national policy on contaminated land management (Darmendrail, 2010). "We are currently identifying key industrial brownfield sites affecting by pollution. With the ambition of creating new eco-neighborhoods, we are funding some key projects that fulfill a set of criteria including environmental sustainable, social diversity and a mix of uses" ${ }^{10}$. This programme specifically focusing on industrial contaminated brownfield sites is up to date the most explicit national consideration and commitment (dedicated funding allocated) towards brownfield regeneration. However, quite limited in its ambitions and means (only a panel of sites have been selected for funding) it won't probably be the starting point for a national commitment towards brownfield sites reuse.

To sum up, despite a set of attempts since the 70s, brownfield regeneration remains in practice a matter for local authorities; despite a national ambition including brownfield sites within perspectives of urban compaction (here defined in opposition to urban sprawl) and issues of soil contamination, brownfield regeneration still suffers from a lack of official recognition. With no official definition, it is

\footnotetext{
9 Grand Projet Urbain" in 1991; "Zone de redynamisation urbaine" in 1996; "Grand Projet de Ville" in 1999; "Opération de Renouvellement Urban" in 2003, Zone ANRU from 2004

${ }^{10}$ Interview with programme leader, May 2010
} 
still a fuzzy matter for dedicated national political interest and commitment despite an overall appreciation of their potential contribution for urban planning (which is clearly addressed by local authorities). "France doesn't have a system in place allowing us to know with how many brownfield sites we need to deal with national wide. But even if an evaluation system was in place it would be quite hard to rely on it as nobody is sharing the same definition ${ }^{11 "}$. This concluding comment made by a city planner is shared amongst with interviews. This results in a separation between discourses, strategies and actions leading to a case by case use of brownfield within one or a set of policy priorities (particularly urban containment, contamination and environmental sustainability, and/or economic development).

\section{Insert Figure 2}

\section{Brownfield land: a late but growing multi-level concern in Switzerland}

French and German languages share a similar linguistic background with regard to the need to define brownfield sites by their former use (using an adjective to the main noun "brache"). However contrary to France, the definition given to these areas in Switzerland has always been limited to their industrial or craftwork function ("friche industrielles \& artisanales", "brachliegende"; "friches industrielles", "Industriebrachen") (see Valda, Wertermann, 2004). As such a set of criteria has been provided to define precisely these sites. In 2008 these sites were explicitly defined as "used or disaffected part of a land dedicated to industrial or craftwork uses. They comprise areas dedicated to rail and militaries uses as well and are particularly useful for urban development" (Valda, Wertermann, 2004)

In contrast to other countries, this commonly accepted definition came quite late due to the late inclusion of cities in planning policies; brownfield sites did not benefit from national consideration till the late-90s when they started to be related to issues of land use (particularly the protection of rural landscapes) and balanced and rational distribution of activities ensuring a harmonious development of the country. This late wake-up took place in reaction to the consequences of the lack of planning policies consequences (Nahrath, 2001; Walter, 1985; Wemegah, 1979, Winkler \& al., 1979) particularly a weak protection of agricultural land, an increase of real estate speculation, an undersupply of housing and a concentration of the land ownership in the hand of private investors (e.g. banks, insurance companies, investment funds) (Nahrath, 2005).

Political interest for these brownfield sites began at the end 1980s through a series of inventories in 1988, 1993, 1996 and 1999 (Valda, Wertermann, 2004). These mapped and measured the significance of industrial brownfield sites but didn't lead to specific political will and further more commitment. As suggested by a government representative "the idea was to have a general overview of industrial unused areas but nobody was committed to take the step forward"12. This interest referred to land use issues and did not result from a defensive attitude towards deindustrialisation. Its impact was in fact relatively minor and only a set of federal policies (Schuler \& al., 2005) targeting specific economically declining regions were implemented (in which brownfield was only indirectly associated). Indeed, even if Switzerland lost 20\% of its jobs in the industrial sector from 1991 to 2001

\footnotetext{
${ }^{11}$ Interview with local head of planning department, June 2010

12 Interview with private consultant, August 2007
} 
(Nahrath, 2004),"the economic, social and urban impacts of de-industrialisation were less important as unemployment rate (3-4\%) and industrial restructuring were minor. Switzerland has never been in the same situation as other countries such as England or Germany. For us it was not a key issue" ${ }^{13}$.

The interest towards industrial brownfield site through land uses has been anchored in the anti-urban tradition (see section 2) and the leading reports that followed the turning situation of the mid $90 \mathrm{~s}$. By 1996, a new vision for urban development led to an emphasis being placed on land use regulation. This was part of a broader engagement of the Confederation towards sustainable development which became a major policy paradigm, stressed in several national strategic reports ${ }^{14}$ as well as in local guidance. In 2000 sustainable development was even acknowledged as a key principle of the new Federal Constitution. In all these documents, land use management and regulation have been considered as an important component of sustainable development. A more parsimonious use of land considered as a "precious and rare good" (Confédération Suisse, 2008b) has been a key recommendation of the sustainable development strategy. As stressed by a represent of the federal administration "I believe from this period there was a general consensus amongst the different governance level that we needed to be more pro-active regarding the reuse of industrial brownfield as we did not have much land available for development" ${ }^{15}$.

Brownfield lands have therefore been positioned as a key concern within these priorities. This explains the recent consideration and commitment of the different levels of governments towards the matter of brownfield reuse. This policy priority became a catalyst for national political interest. The publication of the report on "La Suisse \& ses friches industrielles: Des opportunités de développement au cœur des agglomerations" - "Die brachliegende Schweiz - Entwicklungschancen im Herzen von Agglomerationen" (Valda, Wertermann, 2004) pointed out industrial brownfield sites as a priority which resulted in the identification of a set of deadlocks to regeneration (e.g. pollution) and the promotion of new tools and forms of collaboration. A national census was ordered in 2007; it led to a Federal Action Plan (2008-2011) (Confédération Suisse, 2008a) and the creation of a dedicated website (www.friches.ch) used as an information platform for decision makers, practitioners and owners. This website sits within the project for the regeneration of industrial brownfield (Project "Réhabilitation des Friches Industrielles") supported by the OFEV (Federal Office for Environment) (Lezzi, 2010). This project is precursory to further measures aiming to foster and fasten brownfield regeneration (especially from an economic and legal perspective). Experimentation is currently taken forward in the Argovy canton. In addition, the necessity to take measures to ensure a better use of lands available for development, of brownfield sites and under-used areas are acknowledged in the revised version of the LAT (art.3). In particular building on greenfield lands is going to be more difficult whereas regenerating brownfield will be facilitated (Bühlmann, 2010).

Brownfield regeneration is therefore currently related to the leitmotiv of "urban development inside built up areas" ("développer l'urbanisation à l'intérieur du tissu bâti") stressed in the federal report "Politiques des agglomerations de la Confédération" (Conseil Fédéral, 2001). Brownfields are considered as unique opportunities for promoting the reuse of abandoned and degraded lands in developed areas (Conseil Fédéral, 2003) simultaneously enabling densification, regeneration and

\footnotetext{
${ }^{13}$ Interview with Head of local planning department, June 2007

${ }^{14}$ Such as "Le développement durable en Suisse" in 1997, the "Stratégie du développement durable" in 2002, and in 2008 the "Stratégie pour le développement durable: lignes directrices \& plan d'action 2008-2011"

15 Interview with Head of planning national agency, May 2009. This statement has actually been confirmed in several interviews
} 
preventing urban sprawl. As a result brownfield regeneration as underlined by the Confederation (Confédération Suisse, 2008b) is purposively an answer to economic sustainability (new urban development with moderate cost of network infrastructures), social sustainability (better quality of housing and living) and ecological sustainability (preservation of land stock). Hence, as the policy process towards a national policy for brownfield reuse is still under experimentation and on its way to be completed, it can be argued that Switzerland is moving towards a situation similar to the British case. Brownfield reuse sits within a broader concern of natural landscape protection and land-use planning. Despite therefore a late and slow start, the policy process is launched. The different steps (will, consideration and commitment) are not only connected to each other but the evolution from one stage to the other has been quite logical all along. After remaining stuck at the political will level for a number of years, it has evolved towards an integrated consideration, commitment and localised engagement with private actors (under experimentation in the Argovy Canto). This process actually stresses what Adams \& al. (2010) referred to the iterative process based on testing, experimentation and learning. It also confirms again the importance of adopting one single definition for the object, matter of concern.

\section{Insert Figure 3}

\section{Conclusion}

Despite sharing a decentralised planning system where powers regarding urban and economic development have been devolved to local authorities, France and Switzerland have therefore a distinctive policy trajectory towards the interest, consideration and commitment given at national level to brownfield regeneration. Consequently they do question policy development models described in section 2 particularly with regard to the commitment (or not) of national governments to engage themselves in a national policy of brownfield reuse surpassing general ambitions and discourses.

Switzerland, contrary to France, is definitively in a turning point situation. Up to recently, it could have been argued that the ambition towards brownfield reuse was not raised as an object of national interest, consideration and commitment. However currently the mobilization of the different levels of government consolidated through a series of expected new regulations part of key policy priorities towards land use management highlight a pro-active approach that will need to be assessed in the near future. Such a rapid shift is related to $1 /$ the fact that the country has adopted a precise and limited definition of brownfield sites; $2 /$ has seen in the reuse of this site a way to pursue a pro-active policy towards the protection of natural spaces and urban containment, highly anchored in its antiurban tradition. In the near future, Switzerland might join the categories of countries with dedicated national policies potentially adopting similar tools as in England. Nevertheless, due to the configuration of its planning and governance system, the country will probably find itself constrained between the necessity of maintaining a balance between the different levels of governance and finding a coherence of its national policies. As in Germany (Schulze Baing, 2010), a lot of power and independence will remain in the hands of the local authorities In that sense the American example might be an interesting case to reflect upon especially in the way polluted priority sites have been identified for national funding. 
In France on the contrary despite a sustainable local interest given to brownfield reuse and due to a fuzzy definition given to these derelict industrial and urban sites on top of changing policy priorities (economic development first, then urban containment and soil contamination) there is still no national policy towards brownfield reuse (and there probably never be). At a national level, the country is sustaining its persistent national concern for social housing estates, giving flexibility and leeway to local and regional authorities with regards to land use management and brownfield regeneration. Whereas this highlights an extremely segmented planning and policy system, it also stresses the severe but common shift between discourse and practices related to sustainable planning (Andres, Faraco, 2007) in France. This can be explained by scattered and disjoined political interest, will and commitment as well as by two additional factors. First the fact that increased powers have been devolved to local urban authorities (see section 2 ) and that planning evolved from regulatory to spatial ambitions (POS to PLU, SD to SCOT for example); this has fostered large spatial planning frameworks privileging planning objectives based on territorial cohesion and relevancy than generic and a-territorial frameworks (Zepf, Andres, forthcoming). In addition the attitude towards urbanisation being less defensive than in Switzerland or England, the opportunity to develop a policy anchored in urban containment was challenged by a lack of clear indicators and common frameworks or tools to forbid or restrains new suburban developments (Demouveaux, 2002). It may be worth adding also that immediate critics have been addressed towards the fuzzy nature of sustainable development by experts involved both in academia and in practice (Rumpala, 1999; Ascher, 1998). "The use of this approach is more and more a necessity and, with such a tendency, it doesn't remain a lot of admissible solutions except the one aiming to support a conception built around sustainable development. The problematisation that allows the penetration of this approach in political and administrative environments fosters and constraints any interests to shift or to integrate this new consensus" (Rumpala, 1999). Sustainable development has even been compared to an "indisputable packaging", "a junk notion in which everyone can insert its own preoccupations and objectives" (Ascher, 1998, p.10). Therefore the French case does not conform to the existing models of brownfield regeneration. It has its own model anchored in localised, sectoral strategies and actions based on a case by case basis and deprived from a sole commonly accepted definition of the object of concern.

Looking at these two countries and at how they sit (or not) within other models of brownfield regeneration it can be argued that national and local/regional policies of brownfield regeneration are influenced by a combination of external factors acting as pressures (or freezes) to foster (or not) the reuse of these derelict sites. These pressures relate to the impact of economic downturns on specific areas (impacting the perception of brownfield sites), the powers available for the different authorities (particularly at urban and local level); the existence or not of a set of comprehensive planning instruments, associated to specific targets, fund and grants (that can be complementary to broader European grants) and finally national grassroots (e.g. city psychosis). Overall they raise a broader issue regarding the coherence of decentralised planning system and the need for an integrated planning system linking central level and municipal level. This is actually not specific to this policy matter and has been stressed by Speiling \& al. (2011) regarding for example energy policy in Denmark. This is even more important as any decentralised form of government (federalism or a decentralised planning system) "multiplies the number of veto points at which action can be delayed, diluted or defeated" (Bantin and Costa Font, 2010, p. 383). Consequently the experimentation system, based on a restricted definition of brownfield sites, put in place in Switzerland is worth considering as a best practice particularly as actions and decision tend often to be challenged in a direct democracy. 
On the contrary the French approach can be described as an anti-model that would be worth reviewing; far too dislocated and uncoordinated in term of definition and share of powers and responsibilities, it therefore ignore some important opportunities to take more efficiently benefit of these lands available for redevelopment. 


\section{References}

Adams, D., De Sousa, C., Tiesdell, S. (2010) Brownfield development: a comparison of North American and British approaches, Urban Studies, 47(1), pp. 75-104

Adams, D., Watkins, C. (2002) Greenfields, brownfields and housing development, Blackwell Science, Oxford

Ademe, (2010) Système d'aides aux travaux de dépollution pour la reconversion des friches \& sols pollués, Ademe, Paris.

Alker S., Joy, V., Roberts, P. \& Smith, N. (2000) The definition of brownfields, Journal of environmental planning and management, 43(1), pp. 49-69

Ancien, D. (2005) Local and regional development policy in France: of changing conditions and forms, and enduring state centrality, Space and Polity, 9(3), pp. 217-236

Andres, L., Bochet, B. (2010) Ville durable, ville mutable : quelle convergence en France \& en Suisse ?, Revue d’Economie Régionale \& Urbaine, 4, pp.729-746

Andres, L. (2008) La ville mutable. Mutabilité \& référentiels urbains : les cas de Bouchayer-Viallet, de la Belle de Mai \& du Flon, PhD thesis (dir. Prof. Vanier), UPMF, Grenoble.

Andres, L., Faraco, B., 2007, Territorialisation \& appropriation des normes du développement durable. Agenda 21 locaux : vers un modèle explicatif des différenciations in A. Faure and E. Negrier (Eds.), Critiques de la territorialisation. Les politiques publiques à l'épreuve de l’action locale, pp. 133-139

Ascher, F. (1998) La république contre la ville : essai sur l’avenir de la France urbaine, L’aube, Gémenos.

Aspan (1997) La gestion du bâti vide, Cahier de L'Aspan Suisse, 3, Genève.

Aspan (2004) L'aménagement du territoire en Suisse, ASPAN, Berne.

Barker, K. (2003) Review of Housing Supply - Securing Our Future Needs (Interim Report - Analysis), HM Treasury, London.

Barker, K. (2004) Review of Housing Supply. Delivering Stability: Securing Our Future Housing Needs (Final Report - Recommendations), HM Treasury, London.

Barton, H., Grant, M., Guise, R. (2003) Shaping Neighbourhoods: a Guide for Health, and Sustainability, Vitality, Spon, London

Bartsch, C. (1996) Paying for our industrial past, Commentary,Winter, pp. 14-23

Blanc, M. (2010) The impact of social mix policies in France, Housing Studies, 25(2), pp. 257-272

Bonneville, M. (2004) Les ambiguïtés du renouvellement urbain en France, Les Annales de la recherche urbaine 97, pp. 7-15.

Breheny M. (1992) The contradictions of the compact city, in M. Breheny (Ed), Sustainable development and urban form, Pion, London, pp. 138-159

Breheny, M (1997) Urban Compaction - Feasible and acceptable?, Cities, Vol.14, pp209-217

Breheny, M., Rookwood, R. (1993) Planning the sustainable city region, in A. Blowers (ed.) Planning for a sustainable environment: a report by the Town and Country Planning Association, London: Earthscan, pp. 150189

Bühlmann, L. (2010) Efforts déployés par les pouvoirs publics pour réhabiliter les friches industrielles, Journée d'étude de l'OFEV du 17 juin 2010, Berne

Burton, E. (2000) The Compact City: Just or just compact, Urban Studies, 37(11), pp. 1969-2006 
CABE (2002) The Value of Good Design: How Buildings and Spaces Create Economic and Social Value, Commission for Architecture and the Built Environment, London

Cabernet, 2006, Sustainable Brownfield Regeneration, Cabernet Network Report, Nottingham.

Carmona, M., De Magalhaes C., Edwards, M., Awuor, B., Aminossehe, S. (2001) The Value of Urban Design, report by Bartlett School of Planning for Commission for Architecture and the Built Environment and Department of Transport and the Regions, Thomas Telford, London

Chaline, C. (1999) La régénération urbaine, PUF, Paris.

Cole, 1. (2006) Decentralization in France: central steering, capacity building and identity construction, French Politics, 4, pp. 31-57.

Communautés Urbaines de France, 2010, Les friches, cœur du renouveau urbain. Les communautés urbaines face aux friches: état des lieux \& cadre pour agir, Caisse D’Epargne, Paris.

Confédération Suisse (2008a) Reconversion des friches industrielles \& artisanales -Mesures d'encouragement, Bern.

Confédération Suisse (2008b) Stratégie pour le développement durable: lignes directrices \& plan d’action 20082011, Berne.

Couch, C., Fraser, C. and Percy, S. (2003) Urban regeneration in Europe, Blackwell Publishing, Oxford.

Couch, C., Leontidou, L. \& Petschel-Held, G. (eds) (2007) Urban sprawl in Europe: Landscapes, land use change and policy, Blackwell Publishing Ltd, Oxford.

Dair, C., Williams, K. (2006), Sustainable land reuse: the influence of different stakeholders in achieving sustainable brownfield developments in England, Environment and Planning A, 38, pp. 1345-1366

Darmendrail, D. (2010) The French approach to contaminated land management: legal framework and reclamation of former industrial sites in urban areas, Journal of Urban Regeneration and Renewal, 3(3), pp. 277289

Datar (1991) La réhabilitation des friches industrielles, La documentation française, Paris.

Datar (1987) La réhabilitation des friches industrielles, La documentation française, Paris.

Datar, Lacaze J-P. (1986) Les grandes friches industrielles, Paris, La documentation française.

Demouveaux J-P., 2002, La notion de renouvellement urbain in Gridauh, Droit de l'urbanisme de l'aménagement \& de l'habitat, éditions du moniteur, Paris, pp. 125-140

DETR (1998) Planning for Communities of the Future, The Stationery Office, London

DETR (2000a) Our Towns and Cities: The Future Delivering the Urban Renaissance, Department of the Environment, Transport and the Regions, London

DETR (2000b) Planning policy guidance note 3, Department of the Environment, Transport and the Regions, London.

Dixon, T. (2006) Integrating sustainability into brownfield regeneration: rhetoric or reality? An analysis of the UK development industry, Journal of Property Research, 23(3), pp. 237-267

Driant, J.C., 2009, Les politiques du logement en France, La documentation Française, Paris.

Dull, M., Wernstedt, K. (2010) Land recycling, community revitalization and distributive politics: an analysis of EPA Brownfields Program Support, The Policy Studies Journal, 38 (1), pp. 119-141

Dumont, G. F. (1993) Economie Urbaine: Villes \& Territoires en Compétition, Editions Litec, Paris.

Duxbury, G. (2003) On the Home Front: Improving the Housing Environment and Delivering 'Sustainable Communities' Groundwork Birmingham and Solihull, Handsworth, Birmingham 
Farthing, S. and Carrière, J-P. (2007) Contemporary urban and regional changes and policy problems. In P. Booth, M. Breuillard, C. Fraser C. and D. Paris, Spatial Planning Systems of Britain and France. A comparative analysis, Taylor and Francis, London.

Fina, S. \& Siedentop, S. (2008) Urban sprawl in Europe - identifying the challenge, Real CORP 008 - Mobility Nodes as Innovation Hubs

Freville (2001) Renouveler la ville : les enjeux de la régénération urbaine, FREVille Publications, Lille.

Frey, H (1999) Designing the city towards a more sustainable urban form, Spon Press, London

Ganser, R., Williams, K. (2007) Brownfield development: are we using the right targets? Evidence from England and Germany, European Planning Studies, 15(5), pp 603-622

Gerosa, P.G., Bassand, M., Racine, J-B. (1988) Les enjeux de I'urbanisation en Suisse, Berne, 1988.

Girardon, J. (2006) Politiques d’aménagement du territoire, Ellipses Marketing, Paris.

Greenberg, M., Issa, L. (2005) Measuring the success of the federal government's brownfields program, Remediation, 15 (3), pp. 83-94.

Greer, S. (2010) Territorial politics in hard times: the welfare state under pressure in Germany, Spain, and the United Kingdom, Environment and Planning C: Government and Policy, 28, pp. 405-419.

Hall, P. (1974) The containment of urban England, The Geographical Journal, 140(3), pp. 368-408

Hall, S. and Hickman, P. (2002) Neighbourhood Renewal and Urban Policy: A comparison of new approaches in England and France, Regional Studies, 36(6), pp. 691-696

Haughton G., Hunter, C. (1994) Sustainable cities, Jessica Kingsley, London.

Janin C., Andres L., 2008 La friche: une ressource pour révéler la capacité d'une société à gérer les changements, Annales de la Géographie, 663, pp. 62-81

Jenks, M., Burton, E., Williams, K. (eds) (1996) The Compact City: A Sustainable Form? Taylor and Francis

Kübler, D., Schenkel, W., Leresche, J.P. (2005) Métropolisation, relations intergouvernementales \& la nouvelle politique fédérale des agglomérations en Suisse, in A. da Cunha, P. Knoepfel, J.-Ph. Leresche \& S. Nahrath (eds), Enjeux du développement durable. Transformations urbaines, gestion des ressources \& gouvernance, Lausanne : Presses polytechniques \& universitaires romandes, pp. 359-381.

Lamard, P., Vitoux, MC., 2006, Les friches industrielles, point d'ancrage de la modernité, Lavauzelle, Panazol, $214 \mathrm{p}$

Le Gales, P. (1993) Politique urbaine \& développement local: une comparaison franco-britannique, L’Harmattan, Paris.

Le Gales, P. and Mawson, J. (1995) French urban policy: the implications for regeneration policies in the English regions, Planning Practice and Research, 10(3/4), pp. 379-398.

Le Gales, P. and Tirmarche, O. (2004) Life after industrial decline in St Etienne: Robust SMEs, deterritorialization, and the making of a local mode of governance. In C. Crouch, P. Le Gales, C. Trigilia and H. Voelzkow, Changing governance of local economies : responses of European local production systems, Oxford Press, Oxford.

Le Garrec, S. (2006) Le renouvellement urbain, la genèse d'une notion fourre-tout, Editions du Puca Recherche, Paris.

Lezzi, M. (2010) La revitalisation de friches industrielles du point de vue de l'aménagement du territoire, Journée d'étude de l’OFEV du 17 juin 2010, Berne

Millward, H. (2006) Urban containment strategies: a case study appraisal of plans and policies in Japanese, British and Canadian cities, Land Use Policy, 22(2), pp. 473-485 
Monod, J. \& De Castelbajac, P. (2006) L'aménagement du territoire, PUF, Paris.

Nahrath, S. (2001) Les régimes institutionnels de la ressource sol entre 1870 \& 2000. In P. Knoepfel, I. KisslingNaef and F. Varone (eds.) Régimes institutionnels de ressources naturelles : analyse comparée du sol, de l'eau \& de la forêt, Helbing \& Lichtenhahn, Basel.

Nahrath, S. (2004) Enquête sur la situation des friches industrielles en Suisse, Vues sur la Ville, 8, pp. 3-7

Nahrath, S. (2005) Le rôle de la propriété foncière dans la genèse \& la mise en œuvre de la politique d'aménagement du territoire : quels enseignement pour la durabilité des aménagements urbains. In A. Da Cunha \& al. (ed.) Enjeux du développement urbain durable: transformations urbaines, gestion des ressources \& gouvernance, PPUR, Lausanne.

Nicholls, W. J. (2005) Power and Governance: Metropolitan Governance in France, Urban Studies, 42- 4, pp. 783-800.

Novarina, G. and Pucci, P. (2004) Renouvellement en France/requalification en Italie, Les Annales de la recherche urbaine, 97, pp. 83-89.

Parkinson, M., Hutchins, M., Simmie, J., Clarke, G., Verdonk, H. (2004) Competitive European Cities: Where do the Core Cities Stand?, Office of the Deputy Prime Minister, London

Power, A., Munford, K. (1999) The slow death of great cities? Urban abandonment or urban renaissance, Joseph Rowntree Foundation, York

Raco, M. and Henderson, S. (2006) Sustainable urban planning and the brownfield development process in the United Kingdom: Lessons from the Thames Gateway, Local Environment, 11, pp. 499-513.

Raffestin C. (1997) Une société de la friche ou une société en friche, Collage, 4, pp. 12-15

Rérat, P., Söderström, O., Piguet, E., Besson, R. (2010), From urban wastelands to new-build gentrification: the case of Swiss cities, Population, Space and Place, 16, pp. 429-442

Rey, E. (2006), Régénération des friches urbaines \& développement durable. Vers une évaluation intégrée à la dynamique du projet, PhD, Université Catholique de Louvain, Louvain-la-Neuve

Rey, E. (2007), Des friches urbaines aux quartiers durables, Tracés, 12, pp. 13-15.

Rudlin, D., Falk, N. (1999) Building the $21^{\text {st }}$ century home: the sustainable urban neighbourhood, Architectural Press, Oxford

Rumpala, Y. (1999) Questions écologiques, réponses économiques : les changements dans la régulation publique des problèmes d'environnement au tournant des années 1980 \& 1990 : une analyse sectorielle, PhD thesis, Paris.

Salomon Cavin, J. (2005) La ville mal aimée : représentations anti-urbaines \& aménagement du territoire en Suisse : analyse, comparaisons, évolution, PPUR, Lausanne.

Schuler, M., Dessemontet, P. and Joye, D., (2005) Les niveaux géographiques de la Suisse, Office fédéral de la statistique, Neuchâtel.

Schulze Bäing, A. (2010) Target-driven brownfield reuse: a benefit for deprived areas? A spatial analysis of brownfield reuse patterns in England's core city regions, Journal of Urban Regeneration and Renewal, 3(3), pp. 290-300

Services Techniques de l'Urbanisme (1988) Quel avenir pour les anciennes zones industrielles, Ministère de l’Equipement \& du logement, Direction de l'Architecture \& de l'Urbanisme, Paris.

Solitare, L., Greenberg, M. (2002), Is the U.S. environmental protection agency brownfields assessment pilot program environmentally just?, Environmental Health Perspectives, 110(2), pp. 249-57. 
Sperling, K., Hvelplund, F. \& Vad Mathiesen, B., (2011) Centralisation and decentralisation in strategic municipal energy planning in Denmark, Energy Policy, 39, pp. 1338-1351.

STU (1983) L'enjeu friche industrielle, STU, Paris.

STU (1986) Rencontres diagonales : usines mortes, espaces d'avenir, STU, Paris.

STU, (1988) Quel avenir pour les anciennes zones industrielles, Ministère de l'Equipement \& du logement, Direction de l'Architecture \& de l'Urbanisme, Paris.

Syms, P., Lowe, J., Laidler, D. (2003) Reusing previously development land: perspectives on policies and practices in the European Union, English Partnership/Office of the Deputy Prime Minister, London.

Uhel, R. (2006) Urban sprawl in Europe. The ignored challenge. European Environment Agency, Copenhagen.

Urban Task Force (1999) Towards an urban renaissance: Final report of the Urban Task Force, Spon, London.

Valda, A. and Westermann, R. (2004) La Suisse \& ses friches industrielles. Des opportunités de développement au cœur des agglomérations, ARE, OFEFP, Berne.

Vanier, M. (1997) De l'industrie au territoire : parcours, positions \& perspectives de recherche, HDR, Université de Lyon.

Wachter, S. (ed.) (1991) Redéveloppement des zones en déclin industriel, La documentation française, Paris.

Walter, F. (1985) Fédéralisme \& propriété privée 1930-1950. Les attitudes face à l'aménagement du territoire en temps de crise \& de plein pouvoirs, DISP, 82, pp 21-27.

Walter, F. (1996) Cinquante ans d'aménagement du territoire en Suisse?, DISP, 127, 35-40

Wedding, C., Crawford-Brown, D. (2007) Measuring site-level success in brownfield redevelopments: a focus on sustainability and green building, Journal of Environmental Management, 85, pp. 483-495

Weitkamp, A. (2006) Disturbed Circulation of Land Use - Supporting Brownfield Sites for Sustainable Development of Land, Shaping the Change XXIII FIG Congress, Munich, Germany, October 8-13.

Wemegah, M. (1979) Administration fédérale \& aménagement du territoire. La coordination de l'aménagement du territoire au niveau de la Confédération, Georgi, Saint-Saphorin.

Williams K, Burton E \& Jenks M (eds) 2000: Achieving Sustainable Urban Form, Spon Press

Williams, K., Dair, C. (2007) A framework for assessing the sustainability of brownfield developments, Journal of Environmental Planning and Management, 50(1), pp. 23-40

Winkler, E., Winkler, G. and Lendi, M. (1979) Dokumente zur Geschichte der schweizerischen Landesplanung, Institut für Orts, Regional und Landesplanung, ETH Zurich, Zurich.

Zepf, M. \& Andres, L. forthcoming, Enjeux de la planification territoriale en Europe, PPUR, Lausanne. 


\section{Figure 2: Evolution of urban renewal policies and brownfield site concerns in France}

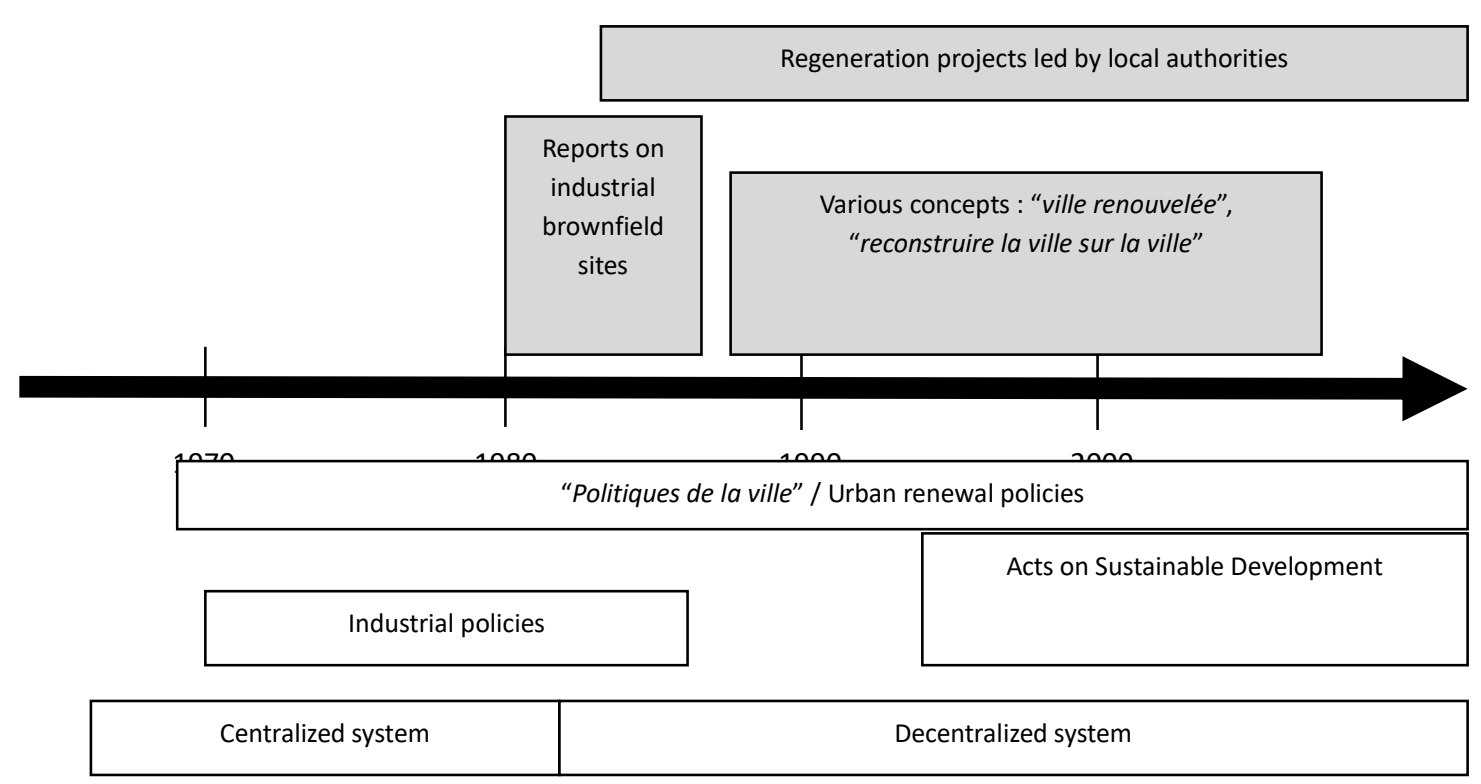

Source: Andres, 2011 


\section{Figure 3: Evolution of planning policies and brownfield site concerns in Switzerland}

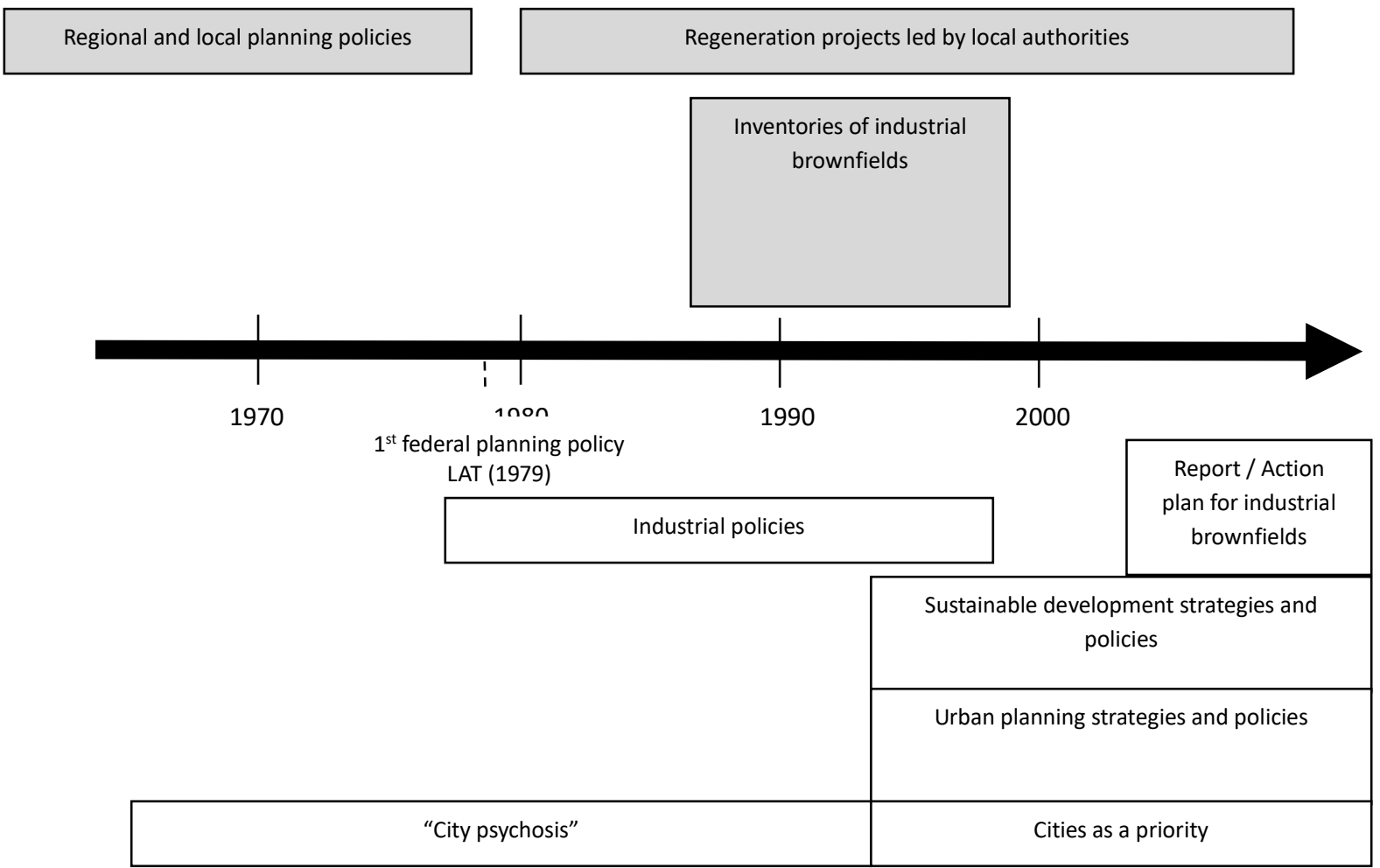

Source: Andres, 2011 